\title{
Order out of Chaos in Toni Morrison's Beloved and Susan Abulhawa's Mornings in Jenin
}

\author{
Abir CHAKER (PhD) \\ University of Skikda \\ Algeria \\ Dr. Ammaria LANASRI \\ Pr. Mokhtar BEN BARKA \\ University of Valenciennes \\ France
}

\begin{abstract}
The present article aims at demonstrating, through the privileged prism of chaos theory, how a number of similarities can be found in two different, although in many ways akin, literary works: Beloved by Toni Morrison and Mornings in Jenin by Susan Abulhawa. Chaos theory has come to take a transdisciplinary dimension and, as such, it has encompassed many fields. Its different key concepts were adapted to domains such as physics, economics, psychology, literature, etc. The present study provides brief definitions of important related key concepts e.g. the butterfly effect, order and chaos, fractal iterations, bifurcation, and strange attractors. The point is to explain how chaos theory has been adapted to literary criticism. And with some concrete examples taken from the two novels, our aim is to highlight the outstanding similarities between them. The logical outcome of our argument is to show how order emerges, dialectically speaking, out of chaos in both literary works.
\end{abstract}

Keywords: chaos theory, butterfly effect, fractal iterations, strange attractors, bifurcation, order out of chaos, Beloved, Mornings in Jenin.

\section{Introduction}

Before the advent of chaos theory, the scientific world was ruled by stability and predictability, on account of the prevalence of the tenets of Newtonian physics. In the eighteenth century, physics and mathematics, under Newtonian guidance tended to envision the whole universe as working clockwise.

Chaos, as it is commonly understood, refers to utter disorder and confusion, but with chaos theory, a dialectics of order within disorder has been introduced. Thus, chaos theory has come to be defined as "the branch of mathematics that deals with complex systems whose behaviour is highly sensitive to slight changes in conditions, so that small alterations can give rise to strikingly great consequences" (the Oxford dictionaries online). This particular theory was developed inside scientific laboratories by using computers in the early 60s, thanks to Edward Lorenz. Lorenz was a meteorologist who established a model based on differential equations. His major discovery consisted in showing that a tiny difference in the initial conditions leads to large changes in the weather as predicted by his model over time. This finding, known as sensitivity to initial conditions, is one of the foundations of chaos theory. Moreover, it provoked a shock within the sphere of mathematics in particular, and science in general. It revolutionised the way scientists perceived the world and the characteristics of the extreme sensitivity to the tiniest changes in initial conditions. They realised that the systems' behaviour are unpredictable even though they are generated by specific equations and rules.

However, chaos theory has come to take a transdisciplinary dimension and, as such, it has encompassed many fields. Its different key concepts were adapted to domains such as physics, economics, psychology, biology, literature, etc. 


\section{The key concepts of chaos theory}

Chaos theory is mainly known for its key concepts which are the cornerstones for any of its interpretation such as the butterfly effect, order and chaos, fractal iterations, bifurcation, and strange attractors.

\subsection{The butterfly effect}

The first characteristic of chaos theory is known as the butterfly effect, the idea being that small or insignificant causes can lead to huge and dramatic effects. Scientifically speaking, it is to be understood as the sensitive dependence on initial conditions - any change in the initial conditions makes the systems react differently, and the reaction is unpredictable even though the system is determined.

\subsection{Order and chaos}

The second feature of chaos theory suggests that there is a place for order within chaotic systems. Whereas "physics operates on a dichotomy of order randomness with nothing in between"; chaos theory, on the contrary, "proposes that the border between order and disorder is actually an area of complex organisation, where order and disorder coexist." (Ward, 1998, 10) In other words, order can be found within chaos.

\subsection{Fractal iterations}

Order, disorder and the sensitivity to initial conditions are closely related to yet another characteristic known as fractal iteration. The iteration in stable systems is called repetition and is due to the feedback phenomenon. It means that the result of the previous state of the system is next used as an initial condition in a second state, which is bound to provoke repetition, and hence stability. However, in chaotic systems, this feedback provokes a change in the initial conditions and the systems' reactions are completely different.

\subsection{Bifurcation}

Bifurcation is used to describe the unexpected change from "a stable system to an unstable/stable one", which means that this change may lead to instability or stability; and this happens at a point known as the bifurcation point. At this point, and " because of various complex factors, the stable point, that is, the state of stability, disintegrates or breaks down and forks, simultaneously creating both stability and instability."(Slethaug, 2000, xxi) The bifurcation point occurs when the system tends to become more and more unstable and when it is driven "beyond the threshold of stability." (Slethaug, 2000, xxi) Then, when the system reaches its extreme points of instability, the bifurcation occurs. As explained by Ilya Prigogine and Isabelle Stengers (1984) in their wellknown book Order Out of Chaos: Man's New Dialogue with Nature: "Whenever we reach a bifurcation point, deterministic description breaks down. The type of fluctuation present in the system will lead to the choice of the branch it will follow. Crossing a bifurcation is a stochastic or a random process, such as the tossing of a coin." (167-177) Therefore, the system's reaction becomes unpredictable.

\subsection{Strange attractors}

Strange attractors are other aspects of chaos theory. This notion is mainly issued from Edward Lorenz's work on meteorology. In her book entitled Chaos Bond: Orderly Disorder in Contemporary Literature and Science, N. Catherine Hayles (1991) explains that "[a]n attractor is simply any point within an orbit that seems to attract the system to it." (147) attractors determine the behaviour of a system, and, in chaos theory, they are termed "strange" because they are unpredictable and chaotic. This concept is well explained by Brian Ward (1998): "All systems possess at least one attractor, which is a point that guides or 'attracts' behaviour. Attractors signify causal structure: they determine the behaviour of systems, and cause events to take place." (153) So strange attractors are very important in a system in that they are bound to cause chaos.

\section{Chaos theory and literature}

All these features characterise chaos theory and have fostered not only its popularity among scientists, but also its interdisciplinary value. Chaos theory was not confined to mathematical laboratories, but it also influenced other disciplines as mentioned before. Its principles are used to give a new impulse to the field of study to which it is applied. This does not mean that all the old concepts are false, but they need to be seen with a new perspective.

One of the most outstanding domains in which chaos theory is used is the literary world. Chaos theory has thus been adapted to literary criticism and its different characteristics are used to study and analyze literary works. As a literary theory, it helps readers grasp some complex ideas, plots, events, and characters. 
To sum up, literary critics successfully used chaos theory as a scientific theory and it was first popularised by chaologists who simplified it and made it accessible to literary critics, who, in turn, adopted it and adapted it to create a new way of exploring literary texts. For instance, as far as the butterfly effect is concerned, as argued by Porush: "without a recognition of the powerful role the butterfly effect plays in human destiny, virtually every great novelist and dramatist, including Shakespeare, would have been out of business" (as cited in Ward, 1998, 13). Thereupon Porush gives the example of Austen's and Tolstoy's novels where insignificant events engender great and often tragic consequences in the characters' lives. In his essay "The Chaos of History: Notes Towards a Postmodernist Historiography" Brian Ward (1996) cites Milan Kundera's novel The Unbearable Lightness of Being, where the protagonist Tomas meets his future wife Tereza thanks to many related events which refer to the butterfly effect:

a complex neurological case happened to have been discovered at the hospital in Tereza's town. They called in the chief surgeon of Tomas's hospital in Prague for consultation, but the chief surgeon of Tomas's hospital happened to be suffering from sciatica, and because he could not move he sent Tomas to the provincial hospital in his place. The town had several hotels, but Tomas happened to be given a room in the one where Tereza was employed. He happened to have had enough free time before his train left to stop at the hotel restaurant. Tereza happened to be on duty, and happened to be serving Tomas's table. It had taken six chance happenings to push Tomas towards Tereza... (13-14)

Besides, according to the author of Strange Attractors: Literature, Culture and chaos theory, Harriet Hawkins (1995), the butterfly effect accounts for many events in literary works like "an inadvertent dropping of a handkerchief, or someone else's otherwise insignificant incapacity to tolerate alcohol (as in Othello) - which can exponentially compound with other effects and give rise to disproportionate impacts." (16)

In her thesis on chaos theory entitled "Reading the Texture of Reality : Chaos Theory, Literature and the Humanist Perspective", Merja Polvinen (2008) explored the literary works of three writers, Tom Stoppard's play Arcadia, John Barth's novels and short stories and Jorie Graham's poem The Dream of the Unified Field. Polvinen (2008) deals with the play, Arcadia, by delving into the paradoxical characteristic of order and disorder which:

is both thematic and structural: the play not only expresses the coherence of human experience in terms of chaos theory's concepts, but it also incorporates the structures found in chaos mathematics in its form. On the one hand, the scenes of the play switch back and forth between the past and the present at an increasing rate, simulating the rhythm of period doublings with which the phases of a chaotic system bifurcate. However, the play ends with a new equilibrium, a scene where the two time periods come together in the form of two couples from different centuries waltzing to the same music, emphasising the harmony of the overall shape over the discordance of the details. (31)

The presence of chaos theory here is clearly seen through the use of time which moves back and forth, between the past and the present, causing the system to bifurcate to achieve balance.

Fractals constitute yet another characteristic that was appreciated by authors to describe a literary work. Among them we can mention Harriett Hawkins and Alexander Argyros. Kellert (2008) refers to Hawkins who studied the poem "The Tyger" by William Blake and who describes it as a work that contains many references to chaos theory because it "contains a comparable complexity of informational content and detail, on every scale" (cited in Kellert, 2008,196)

In The Literary Canon as a Dynamic System of Chaos and Complexity Theory, Martin Thomas Meadows (2006) argues that in poetic exploration, chaos theory is also relevant to study a poet like Walt Whitman. He explains that any new literary work study will enhance its importance and will be a departure for another one, and this may be compared to chaos theory in which the characteristic of feedback leads to iterations where the results are used as initial conditions to lead to iterations. This notion can be compared to what is known in literary jargon as "palimpseste" in which a literary work in its apparent state shows traces of an earlier version of another literary work. (25)

Another interesting example in which chaos theory is scrutinized is Gordon E. Slethaug's (2000) book Beautiful Chaos: Chaos Theory and Metachaotics in Recent American Fiction. The author genuinely addresses the issue of applying chaos theory to some instances of American fiction, and declares that: "It is surely chaos theory that can help to explore, if not entirely explain, the mysterious and complex in narration, culture, and life." (xv) 
Slethaug (2000) studied other works for which he used chaos theory through some of its aspects, narrative forms and use of time. We can mention Don DeLillo's White Noise, Thomas Pynchon's The Crying of Lot 49, Carol Shield's Stone Dairies, and John Barth's On with the Story. Slethaug (2000) argues that "None of these texts use aspects of chaos theory naively and innocently; they all confront it self-consciously, intelligently, and analytically." (xiv) He also gives examples of writers who use chaos implicitly, especially in their use of the narrative point of view, like in Toni Morrison's The Bluest Eye and Michael Dorris's A Yellow Raft in Blue Water.

\section{Order out of chaos in Toni Morrison's Beloved and Susan Abulhawa's Mornings in jenin.}

Relying on such examples, we have come to study Toni Morrison's (1987) Beloved and Susan Abulhawa's (2010) Mornings in Jenin according to the tenets of chaos theory. Not only will our study highlight key concepts of chaos theory but it will also shed lights on the similarities between the two novels, providing thus, a new approach to these two masterpieces.

The aspect of chaos theory which will be investigated here will be focussed on the order that can emerge out of chaos in both Beloved and Mornings in Jenin. From the chaos that characterises the two novels, a certain kind of order and stability finally come out. However, before describing the order that comes out of chaos, some questions related to both chaos theory and the two novels must be asked and answered: What is the chaotic system in the two books? What is/are the initial condition(s) that is/are related to the chaotic systems in the two books? How does the butterfly effect become evident within each chaotic system? How do the fractal iterations manifest in each chaotic system? And finally how does order emerge out of chaos?

Toni Morrison's (1987) Beloved and Susan Abulhawa's (2010) Mornings in Jenin are about remembering a very painful past, a past which has had a damaging impact on all the characters' lives. The way in which the past, the present and the future are represented in the two books makes it possible to adapt and apply chaos theory to compare and analyse the two books.

Both Beloved by Toni Morrison and Mornings in Jenin by Susan Abulhawa are romans à clef since they tell the story of fictional characters who live through real history. Beloved reopens a painful page of American history, that of slavery and Mornings in Jenin deals with Palestine issue and the Palestinian community. Even though different, the two novels share a common and important point; they are timeless and can be adapted to any time. Beloved and Mornings in Jenin can, both, fit with the categories of fictional history and family saga. Through the three main characters: Sethe, Beloved and Denver, Beloved becomes a tribute to the Afro-American community for what it endured. Mornings in Jenin is intended to the Palestinian community all around the world. Like Beloved, it is not about what the Israeli did, but about what the Palestinians endured and are still enduring. It deals with Abulheja family, and more specifically with the three main characters: Dalia, Amal and Sara. A close look at these two historical novels shows us that in fact they function as chaotic systems, mainly regarding their plotlines. In both Beloved and Mornings in Jenin the reader has to read through to find out what has happened to the characters. In both books, there are different narrators. In Beloved for example, there are Sethe, Beloved, Denver, Paul D. Some passages are even so complex that the narrator cannot be identified while in other passages, the three narrators' voices - Sethe, Beloved and Denver - join, as shown in the following passage:

Beloved.

I will make you a round basket.

You're back. You're back.

Will we smile at me?

Can't you see I'm smiling?

I love your face.

We played by the creek.

I was there in the water.

In the quiet time, we played.

The clouds were noisy and in the way.

When I needed you, you came to be with me.

I needed her face to smile.

I could only hear breathing.

The breathing is gone; only the teeth are left.

She said you wouldn't hurt me.

She hurt me. 
I will protect you.

I want her face.

Don't love her too much.

I am loving her too much.

Watch out for her; she can give you dreams.

She chews and swallows.

Don't fall asleep when she braids your hair.

She is the laugh; I am the laughter.

I watch the house; I watch the yard.

She left me.

Daddy is coming for us.

A hot thing.

Beloved

You are my sister

You are my daughter

You are my face; you are me

I have found you again; you have come back to me

You are my Beloved

You are mine (Morrison, 1987, 215-16)

In the same way, Mornings in Jenin shares the same point related to the main narrator's voice. The reader is presented with two distinct points of view: the first person Amal and the third person omniscient Yousef (Amal's brother) in addition to the stream of consciousness that accentuates the complexity of the text and the plot. Which can be described as a chaotic system, complex but not predictable:

I listened . . the heavy syllables pounding my sense of what was real. Rocking on the floor in my own two arms, I pressed the telephone receiver to my ear. I was not filled with grief, anger, or even love. Nothing came over me. But everything rushed out. Yousef's words now travelled through me like a stream, pulling life from the cells of my body and gathering it beneath me. Memories of rain beating on the windshield of Majid's Fiat; the calluses on his feet when they rubbed against my bare legs; the hair on his chest when I lay my head there; the lines around his mouth when he laughed; the arch in his brow that was a smile of its own; the small wrinkles beneath his ears; the smooth skin on his back when he sat up in bed; his touch, his kiss, his integrity, his love. . All of it pooled on the floor around me like a tenebrous underbelly. Until at last, I sat captive in a vacuum of thought, numb and rocking on the floor, still holding the receiver as my brother's voice, with its unbearable sadness, faded in that emptiness. Majid. My love. The dreams he and I had dreamed circled around this new reality. The children we would have, the places we would go, the home we would build, the laughter we'd share and the songs we'd sing, the life we'd live, the love . . o oh the love we would love, danced like ring-around-the-rosy, around the reality that Majid was dead. Killed. Ashes, ashes, all fall down. (Abulhawa, 2010, 175-76)

In this significant passage, Amal is confronted with the death of her husband, Majid - All the reminiscences emerge in her mind and all the dreams and future plans she made with him are eternally buried with him. The passage highlights to what extent she is overwhelmed by her grief making words come to her mind in an unstoppable flow of thoughts and words. The chaotic systems in the two romans à clef rule the developments of the plots, and especially those of the characters. In both Beloved and Mornings in Jenin the characters are fictitious; however, their real equivalents can be found in real life in the social system they represent. In Beloved, Sethe and Denver are described as accustomed to living in 124 Bluestone Road, a haunted, spiteful and full of a baby's venom place. Sethe works in town and Denver does not step outside the house. And in Mornings in Jenin Yehya Abulheja, his wife Bassima, and their two sons live in the calm and harmonious village of Ein Hod. Hasan, the elder son, had built up a peculiar friendship with a young Jew, Ari Perlestein, and years later he marries Dalia the mother of his children. However, in both books, along with the development of the plots, the life that the characters have is not going to last because of a small change in the initial conditions.

In Beloved the small change in the initial conditions is not only materialized in the arrival of first Paul D and then Beloved, but also in slavery itself. Sethe as a main character lives in a state of denial of the past - this shameful past is directly related to slavery - a very painful one that she does not want to remember. The insignificant event symbolised by Paul D's arrival at 124 Bluestone Road is the first change in the initial conditions in Sethe's life. 
With his arrival Sethe finds herself faced with the same past that she tries to repress and forget and to all the reminiscences related to her personal past. The change occurs because Paul D makes Sethe talk about one of the most painful incidents in her life, the nephews' stealing of her milk, rape and the schoolteacher's whipping. So we can see here how the insignificant arrival of a character gives rise to an unpredictable and big reaction, manifested in the remembrance of a long buried past.

The second change in the initial conditions is signaled by the insignificant finding of a young girl with a baby's skin, with the insignificant name, Beloved, on the porch of 124 Bluestone Road. However innocent she may seem, this girl creates a shock wave, not only within Sethe, but also within the whole Black community. Beloved drives Sethe to talk, not only about her past when she was too young to remember, but also about the infanticide that she committed against her baby girl years ago. In addition, she is the one who makes Paul D and all the Black community face and remember their too painful past as former slaves. In Mornings in Jenin, the tiny changes in the initial conditions can be grouped under the term of War. War is considered by critics as a small change in the initial conditions because its consequences are unpredictable and dramatic, as pointed out by Vicente Valle Jr.(2000), in his article entitled "Chaos, Complexity and Deterrence": "the [chaos] theory seems apt in reminding us that actions can have unforeseen consequences and that war can be an unpredictable affair."(4) The IsraeliPalestinian wars, which are depicted through the grim landmarks of 1948, 1967, and more recently 2002, are wars with unpredictable consequences on both the characters' lives and on the Palestinian community as a whole.

As seen in the definition of the butterfly effect, any tiny change in the initial conditions provokes unpredictable and irreversible consequences. In Beloved, the butterfly effect is not only unpredictable and irreversible, but it is also very impressive. Furthermore, the butterfly effect is perceived in some characters, but also in the whole Black community. Paul D's insignificant arrival at 124 Blues Stone Road drives Sethe to narrate one of the most painful episodes of her life. Before his arrival Sethe had constructed a shell to protect herself from remembering her past. The butterfly effect here is shown in the character of Sethe when she talks about what happened to her - she coped with her past and buried it - but Paul D's resurrection from her past makes her remember the day of her milk stealing, rape, whipping and understanding that her situation was that of an animal. So Paul D's insignificant arrival engenders cracks in the shell that she took years to build.

Beloved's arrival at 124 Bluestone Road is the crucial butterfly effect, the one that is going to break, not only Sethe's shell, but also Sethe as a person. At the beginning, Beloved is portrayed by Morrison as an innocent baby girl who has no control of her body. Soon after, Beloved becomes stronger and starts to ask Sethe questions about her past. Instead of running away from her memories, Sethe is so profoundly immersed in her past that she is taken back to her own childhood. Sethe's painful journey all the way into her painful memories makes her realise that she has never known her mother, that she forgot the language that her ancestors used to speak and the antelope dance, the dance that her ancestors used to dance in Africa. She also understands that her mother has never been allowed to nurse her and take care of her. Worse than that, Sethe realises, for the first time in her life, that her mother was about to abandon her and to run away. This provokes in her painful feelings. Beloved's questioning makes Sethe become weaker. Instead of enjoying her freedom, Sethe finds herself trapped in her painful past.

Beloved is also the catalyst of Paul D's own butterfly effect - she does not only prevent him from reaching the stability that he had been seeking for many years, the family that he had always dreamed of with Sethe and Denver, but she also makes him remember his painful past as a slave; she makes him open the tiny tobacco box where he had meticulously locked his memories. And he is thereby obliged to memorize how he has been badly treated. He is also forced to remember how, every morning, while imprisoned, he was forced to perform oral sex on white men, which is also considered as a form of rape. Because Beloved stands for the past, she functions as the vehicle of the butterfly effect on both Denver and on the whole Black community. For Denver she is the past that she has never known - she was born free and did not go through the painful experience of slavery. As a result, Denver is obliged to hear all the atrocities caused by slavery and she is obliged to live in the past instead of living only in the present and remembering the moment of her birth; the story that she loved most. Before Beloved's arrival, Denver was living alone in the house with her mother, her two brothers left because of the ghost and Baby Suggs, her grandmother, died. For the Black community, the opposite occurs; Beloved obliges them to face the reality of their communal past as slaves. It is this confrontation that makes them realise what they did to Sethe by excluding her from their community because of her infanticide. Beloved also makes the Black community realise that they were hypocritical towards Sethe since many women had committed the same 
infanticide when they were slaves, except that it was not for the same reasons. This result was really unpredictable within the black community because since Sethe's horrible action against her baby girl, no one had stepped inside 124 Bluestone Road's yard. Slavery as a change in the initial conditions really brings about the most important butterfly effect that is unpredictable and very impressive. Set he was born on a plantation and before she knew how to pronounce her name, she was submitted to the system of slavery that not only prevented her from knowing her mother, but also transformed her.

This left psychological and physical stigma in Sethe; it affected her psychologically through her mammary rape and physically through her whipping. Slavery which made Sethe run away from Sweet Home comes back twenty-eight days later in the image of the schoolteacher, and it is, at that very precise moment, that the unpredictable happened. In order to protect her little baby from slavery, she simply killed her. This infanticide crystallises the butterfly effect. It is also this crime which provokes another butterfly effect, mainly symbolised by Sethe's and Denver's forced isolation. And which drives Howard and Buglar, Sethe's two sons, to leave their mother and sister. In the same way, it makes Baby Suggs realise that she has no idea about what freedom means, and she understands that Black people need more time to accept their freedom for they don't know who they are. As a result, she decides to wait for death in her bed to free herself. It is also this infanticide that forces Paul D to abandon Sethe because he could not accept a love which he described as too thick.

Slavery provokes the butterfly effect as it drives people to commit unbelievable deeds that the human mind cannot integrate. Ella's rape by a white father and his son made her take the ultimate decision of committing a sexual molestation, not to nurse the consequence of this rape: a white baby. Thus, indirectly she kills her baby, just as Sethe did. Slavery also drives Stamp Paid to kill his own wife to put an end to the long nights of rape imposed on her by her white master. Baby Suggs was prevented from loving her children and couldn't be a normal mother since her children, except Halle, were sold.

In Mornings in Jenin, it is war that is the main catalyst of the butterfly effect.

The first in a long list of wars that turned the Abulhejas' life upside down is the 1948 War. It uprooted Abulheja family from their beloved land, trees and country, Palestine. This war is to have drastic consequences on Abulheja family in general, and on Dalia, in particular, since her second son, Ismael, is snatched away from her. This event is the backbone of all the Abulheja family's torments. It is during their new life in the refugee camp in Jenin that, day after day, all the family becomes conscious of their unfair status as refugees. Dalia's loss of her son marks the beginning of her own psychological disorders - she is driven bit by bit into the abyss of her own unconscious. It transforms her into a cold and non-demonstrative mother. Then the 1967 war occurred, bringing with it a kind of hope to the refugees in Jenin; however, the opposite happened. Many people died, and among them Amal's father. His death symbolises that of a beautiful, intellectual dawning romance between Amal and her father. That year also marks Yousef's transformation into a new person who takes political decisions and who joins the PLO (Palestinian Liberation Organisation). The war allows the meeting between the two enemy brothers Yousef and David, alias Ismael, the Palestinian boy raised by a couple of Jews. It also stands for Amal's nightmare. With Huda, they both witnessed the death of baby Aicha in the kitchen's hole. It also marks the end of the strong and free-spirited Dalia, Amal's mother, who ends up insane and dies alone. Amal is sent to the orphanage to carry on with her studies. She will find herself later alienated once in the USA whereas, just like Sethe, she tries to forget her painful past. Like Sethe she built a solid shell for herself, which separates her from all that is related to Palestine.

The 1982 war accomplishes the destruction and chaos that the two other wars had failed to bring about. It not only destroys Amal and her brother Yousef, but also thousands of Palestinians who died in the Sabra and Shatila massacres. Amal reinforces her shell after it has been softened by Majid's presence and love; this latter war snatched Majid's life and with his death Amal's hope dies and she is transformed like her own mother into an icy woman. The last stroke of fate is marked by the tragic death of Yousef's entire family. He lost everything that he ever loved, and he couldn't cope with pain and grief. As a result, he swears revenge. In her article, "Emerging Patterns: Chaos and Order from the Mind of Nadine Gordimer", Elizabeth Howell Brunner (1999) explains that "The principle of fractal iteration demonstrates a brutal correlation: the distortion of social chaos repeats itself in personal chaos." (2) In both Beloved and Mornings in Jenin we can find fractal iteration because both works deal with fictional social systems. In Beloved, the social system is represented by the Afro-Americans, but also by some whites. And the same situation is found in Mornings in Jenin, the social system being represented by the Palestinians, and by some Jews. But before identifying the fractal iteration on the individual level, we have first to identify it on the social level. 
In Beloved there is a general chaos within the whole Black community, and it is caused mainly by slavery. This chaos is embodied in Beloved's character, because she is the past, and she represents the Sixty Million people and more who died in the middle passage, and to whom Toni Morrison dedicated Beloved. Chaos in fact starts, first on the coast of Africa, and then on the ships crossing the Pacific Ocean, and finally in the United States on several plantations. Fractal iteration is represented by the whites who are perpetuating the traditional institution of slavery generation after generation.

Beloved is also full of individual examples of fractal iteration, the first one that can be mentioned is once again Beloved. She belongs to the fourth generation of slave women except that she did not go through the physical experience of slavery. Sethe can also be considered as fractal iteration, because like her mother, and because of slavery, she killed her baby girl. Her mother did the same, when she refused to nurse the white babies, the results of her rapes. There is also Ella who refused to nurse her white baby, after her rape by a father and his son.

Mornings in Jenin features the same characteristic of fractal iteration, both on the individual and collective levels. In the latter, chaos is mainly caused by the destructive wars. The fractal iteration caused by the chaos of the war of 1948 is characterised by the uprooting of millions of Palestinians from their beloved lands and homes, by the clearances of villages through massive killing like in Deir Yacine, and the creation of refugee camps where thousands of Palestinians are obliged to live. The 1976 war also led more Palestinians to death or to become refugees - they were obliged to live as stateless persons in refugee camps like those of Jenin and Sabra and Shatila.

This war also provoked a kind of apartheid system where non-Jews were not allowed to live in Jerusalem. The refugee camps were guarded by heavily armed soldiers and, in order to move from one check point to another, Palestinians were obliged to show many passes. On the individual level, fractal iteration in Mornings in Jenin, just like the one in Beloved, is tightly related to four generations of Palestinian women. Starting with Sara, Amal's daughter, she represents the same fractal iteration as her mother Amal. She lives in the USA where she does not know anything about her parents' past, and where she has a biased story about what really happened to her father Majid and uncle Yousef. Sara is just like Amal when she was young; she lived with her mother, Dalia, who hid her emotions to her children. In addition, Amal lost her father in the 1967 war and was not able to discover what happened to him; she was injured by an Israeli bullet when she was twelve. And finally she lost all the dearest people to her heart, her husband Majid, and her brother's family. Amal is just like her own mother Dalia, who represents the same fractal iteration with some tiny differences. In 1948 Dalia lost her son. He was snatched from her, while being moved from their beloved village, Ein Hod. This terrible incident and the loss of her husband in 1967 gradually drove her insane. So the butterfly effect of war and slavery was just like a tornado which wiped out everything around it. However, some order can be observed within the many episodes of chaos. This order is imprisoned between two periods of chaos forced by insignificant changes in the initial conditions. In Beloved and Mornings in Jenin the interaction of order and disorder is thematic and structural. The two books not only incorporate many characteristics of chaos theory, but they also evince the same form of chaos theory. On the one hand, their structures switch back and forth between the past and the present according to a crescendo pattern, thereby simulating the rhythm of period doublings with which the phases of a chaotic system bifurcate. And on the other hand, the two plots end up with a new balance between the two time periods when the past and the present come together, and thereby a certain kind of order can be found.

In the plot of Beloved, there are different narrators, Sethe, Beloved, Paul D, and Denver; almost all these characters are telling their own stories through a continual shift between the past and the present. Every character makes many journeys through time to the extent that the reader can sometimes be confused, especially when the shift between the past and the present is mixed with the stream of consciousness and the narrators are not recognisable. Sethe's first journey is related to Paul D's arrival, when he induced her to speak about her mammary rape and whipping, a trip harder than the one she undertook from Sweet Home to 124 Bluestone Road. When narrating all that happened to her, Sethe's story is interrupted by a long description about the present. The second trip is provoked by Beloved's continual questioning of Sethe about her past - she forces Sethe to talk about her childhood and her infanticide. Moreover, through Beloved's narration, the reader finds himself on a ship among Black Africans in the Middle Passage, and then (s)he is taken back to the present through Denver's description of Beloved. Many other examples about the shifting back and forth between past and present can be found in Beloved because it is the backbone of Morrison's technique of writing in this book - a technique known as retrospect. This shift is symbolised by the coined portmanteau word, rememory, a combination of remembering and memory. 
In Mornings in Jenin we also find the technique of shifting between present and past because, first, the story is narrated by the protagonist Amal who tries to reconstruct her family's history through her memories. What is worth mentioning, and closely related to the shifting back and forth between present and past, is a beautiful mixture of present and past tenses to put an emphasis on this journey.

For example, in the last chapter, Amal sometimes employs the present tense when talking to her brother David, alias Ismael, and the past tense to describe her mother and her life in Jenin.

As mentioned earlier, in both Beloved and Mornings in Jenin, there are many periods of order encased between two periods of the chaos caused by the butterfly effect. First in Beloved, there is order locked up between the chaos caused by Paul D's arrival and Beloved's arrival. But before, there is a first period of order which lasts twenty-eight days. To experience this order, Sethe is obliged to undertake a long and painful journey from Sweet home to 124 Bluestone Road; there, at her arrival she is able to love all her children. However, this new and delicate stability is harshly destroyed by the arrival of the schoolteacher who claims his property, and Sethe commits the unpredictable crime of killing her baby daughter. And this act spells the end of order.

The order that comes after Paul D's arrival is symbolised by Sethe's ability to move forward from the episode of her rape to the acceptance of the past. By naming and accepting her mammary rape and whipping, Sethe breaks the shell that she created many years ago. The order is also symbolised by the fact that Sethe decides to leave the door open for a new and beautiful future between her and Paul D. But the fragile equilibrium of the new family is threatened by Beloved's arrival and the system is henceforth bound to shift to another period of chaos. Nevertheless, the latter is going to give birth to another period of order when the present meets the past. This happens mainly in the final scene of Beloved when the black community decides to free Sethe from Beloved's control. It is because Beloved represents the past of both Sethe and the black community, that we have a meeting between past and present. In addition, then, order is symbolised by Beloved's disappearance, which is an image of the chaos that is going to give birth to Sethe's new life, where there is a new place for the future to be written. This possible future is strengthened by Paul D's coming back to Sethe and by Denver's new life as an active Black woman within her community. This open end allows the readers to use their imagination to write this future - it is a message of hope addressed by Morrison to her community.

Like Beloved, Mornings in Jenin also includes periods of order and disorder. The chaos that the war of 1948 provoked among the Palestinians in general, and within the Abulheja family in particular, is bound to give birth to some order exemplified by the new way of living at the refugee camp in Jenin. Daily routines take up again gradually in the refugee camp - marriages are celebrated again, and the first generation of Palestinian children is born.

The second episode of chaos provoked by the 1967 war signals yet another period of order symbolised by Amal's departure and by her new life in the USA - a life constructed around a perpetual denial of her Palestinian identity and against which, like Sethe, she builds a shell to protect herself. This order is reinforced by her coming back to the state of refugee when she moves to live in Sabra and Shatila, where she meets her future husband, Majid. Like Sethe, Amal opens a door through which happiness can enter, and a possible balance can be reached with Majid, and with her brother Yousef and his small family. Yet, the equilibrium is threatened by the Israeli bombing of Beirut and the genocide of Sabra and Shatila; where another destructive period of chaos is to take place. It is represented by Majid's death closely followed by the tragic death of her brother's family.

This last period of unbearable chaos for Amal is followed by the final state of order reincarnated and provoked by David, Amal's Jewish brother. David's arrival opens again both Amal's and David's wounds. Through the narration of her so much repressed past, she provides a justification for her daughter, concerning her state of mother, and allows herself to show openly her love to her daughter, Sara. Equilibrium is reached when the past and the present join through Amal and Sara's journey to Palestine. There, Amal is able to heal all her wounds and meets her father's dear friend, Ari Perlestein, who fills all the empty pages about her past. But as she is with her daughter at Jenin's refugee camp, a final period of chaos takes place with the Israeli attack on this camp. Amal is killed trying to save her daughter's life and, like Beloved, she disappears from the world leaving a place for a future. What is more important is the fact that Amal helped unveil the mystery of her brother's Yousef destiny. Yousef was wrongly accused of committing the bombing suicide at the American embassy in Beirut; just as Amal had always thought; Dalia's education of Yousef is based on the profound respect of life. 
Amal's death provokes a shock wave within David who becomes able to go beyond his alcohol addiction. In this way, a kind of order between many chaotic episodes is found, and thus order emerges out of chaos.

\section{Conclusion}

Chaos theory has demonstrated that literary criticism is in constant evolution. It has provided a relevant, new, stimulating, thought-provoking perspective to study and better understand literary works. This theory makes it possible for the readers to identify how chaos comes to occur because of a slight change in the initial conditions, how it comes to a maximum when bifurcation happens, and finally how order emerges out of chaos. In Toni Morrison's Beloved and Susan Abulhawa's Mornings in Jenin, chaos theory has been found in different avatars: in the plots, in the events and within individual characters or groups. Although different at first glance, the comparison between the two novels, taken through the prism of chaos theory, has revealed many similarities which culminate in the order that finally emerges out of chaos. In this way, it has helped to build the bridge between Beloved and Mornings in Jenin.

\section{References}

Abulhawa, S. (2010). Mornings in Jenin. New York: Bloomsbury USA.

Hawkins, H. (1995). Strange Attractors: Literature, Culture and chaos theory. New York: Prentice Hall/Harvester Wheat sheaf.

Hayles, N. C. (1991) Chaos Bound: Orderly Disorder in Contemporary Literature and Science. New York: Cornell University Press.

Howell Brunner, E. (1996). Emerging Patterns: Chaos and Order from the Mind of Nadine Gordimer. Paper presented at the Seminar on Women Writers for English 459. Retrieved from http://elizbrunner.tripod. com/Scholar/GordimerOne.htm

Kellert, S. H. (2008). Borrowed Knowledge: Chaos Theory and the Challenge of Learning across Disciplines. Chicago and London: The University of Chicago Press.

Meadows, M. T. (2006, May). The Literary Canon as a Dynamic System of Chaos and Complexity Theory. [MA. Thesis]. Oklahoma State University. Retrieved from http://digital.library.okstate.edu/etd/umi-okstate1726.pdf

Morrison, T. (1987). Beloved. USA: Penguin Group.

Polvinen, M. (2008). Reading the Texture of Reality: Chaos Theory, Literature and the Humanist Perspective. [Doctoral dissertation (monograph)]. University of Helsinki.

Retrieved from https://helda.helsinki.fi/bitstream/handle/10138/19233/readingt.pdf?sequence=1

Prigogine, I. \& Stengers, I. (1984). Order out of Chaos: Man's New Dialogue with Nature. USA: Bantam New Age Book.

Slethaug, G. E. (2000). Beautiful Chaos: Chaos Theory and Metachaotics in Recent American Fiction. Albany: State University of New York Press.

The Oxford dictionary on line.<http://www.oxforddictionaries.com/fr/definition/anglais/chaos-theory>.

Valle, Jr. V. (2000). Chaos, Complexity and Deterrence. [Seminar paper]. National War College. Retrieved from https://pdfs.semanticscholar.org/173f/f3d99b0a026bfa8def87b1bd73819a12d43d.pdf

Ward, B. (1998). The Literary Appropriation of Chaos Theory. [Doctoral Thesis]. The University of Western Australia. Retrieved from https://indolentdandy.net/phd/

Ward, B. (1996). The Chaos of History: Notes towards a Postmodernist Historiography. $\quad$ LIMINA, Volume 2, 817. <http://www.archive.limina.arts.uwa.edu.au/_data/page/186553/2ward2.pdf>. 